\title{
DINAMIKA KERUKUNAN UMAT BERAGAMA KOTA AMBON BERBASIS ADAT PERSPEKTIF MASLAHAH
}

\author{
Abdul Muher \\ Mahasiswa Pascasarjana UIN Alauddin Makassar \\ Email: abdulmuher81@gmail.com
}

\begin{abstract}
ABSTRAK:
Dinamika kerukunan umat beragama Kota Ambon yang berbasis adat efektif dan maslahat untuk berjalan bersama menata kehidupan yang rukun dan toleran. Nilainilai lokal seperti: a. Ale rasa beta rasa, untuk saling merasakan satu sama lain), efektif dalam konteks toleransi dalam beragama. nilai-nilai lokal itu merupakan ekspresi manusia yang berbeda agama untuk saling merasakan baik senang maupun susah dirasakan bersama-sama; b. Katong samua basudara, pada hakikatnya manusia itu bersaudara dari keturunan yang satu; c. Siwa Lima, untuk menyatukan masyarakat Ambon tanpa perbedaan), dan fungsionalnya untuk menyatukan semua seluruh masyarakat Ambon-Maluku pribumi maupun pendatang tanpa memandang pada agama; d. Pela gandong, yaitu menjalin kekerabatan yang seagama (IslamIslam), (Nasrani-Nasrani), dan yang berbeda agama (Islam-Nasrani).

Kata kunci: Kerukunan, adat, ma lahah
\end{abstract}

\section{ABSTRACT:}

The dynamic of religious society peacefulness in Ambon on the base of custom from maslahah perspective has been undoubtedly effective and benefitful to maintain peacefulness and tolerance. Local values such as: a. Ale rasa beta rasa, to feel each other), has been effective in the comtext of tolerance in religious live. These local values are humanity expressions of different religions to share both happiness and bitterness together; b. Katong samua basudara, basicly express men are brothers of one anxious; c. Siwa Lima, to unite Ambonese without differsity), and functionally unite the whole native Ambon-Maluku society and the comers without seeing their religions; d. Pela gandong, which is corresponding Moslems to Moslems, Christians to Christians, and Moslems to Christians).

Keywords: Peacefulness, custom, ma lahah

\section{Pendahuluan}

Bangsa Indonesia merupakan bangsa besar yang ber-Bhinneka Tunggal Ika (berbeda-beda tetapi satu). Masyarakat kepulauan Indonesia selalu memegang kebersamaannya secara luas, dari basis-basis masyarakat lokal atau masyarakat adat. Masing-masing komunitas adat masyarakat kepulauan di Indonesia disebut masyarakat Nusantara, memiliki aneka tradisi dan kearifan lokal (lokal wisdom), kearifan masyarakat asli, serta kearifan agama. Kenyataan ini membuat masyarakat Indonesia dikenal sebagai masyarakat yang beranekaragam etnis, beranekaragam budaya (multikultur), serta beranekaragam agama (multi religious). 


\section{Tahkím}

Vol. XIV, No. 1, Juni 2018

Bangsa Indonesia dari aspek budaya, merupakan bangsa yang kaya dan indah dengan aneka kearifan lokal dalam penyelenggaraan hidup masyarakatnya. Sebagai konsekuensinya, tidak mudah untuk membangun kearifan hidup berbangsa yang besar, terlepas dari aneka sistem kearifan lokal yang dimiliki oleh masyarakat lokal yang menyebar dari Sabang sampai Merauke. Dari aspek keagamaan bangsa Indoensia dikenal sebagai masyarakat majemuk (plural) disebabkan hampir semua agama khususnya agama-agama besar terwakili di Indonesia. Senafas dengan itu, masyarakat Indonesia pula terbangun di atas keanekaragaman etnis, budaya, dan bahasa yang tersebar di ribuan pulau, sehingga bangsa ini memiliki penghayatan dan pengalaman unik dibanding dengan bangsa-bangsa lain. ${ }^{1}$ Islam adalah agama yang sangat mengapresiasi keragaman kehidupan umat manusia. Keragaman atau keanekaragaman adalah sebuah keniscayaan, dan kehadiran Islam menjadi sebuah ikatan keragaman kemanusiaan tersebut tanpa sekat dan pemisah.

Pada masa Orde Baru masalah kerukunan umat beragama dapat dikatakan berjalan dengan baik, aman dan harmonis. Namun berakhir masa Orde Baru bergolak konflik. Salah satu konflik pernah terjadi di Indonesia adalah konflik Ambon (Maluku) pada 19 Januari tahun $1999 \mathrm{M} / 1$ Syawwal $1419 \mathrm{H}^{2}$, yang menyebabkan penderitaan berupa kemiskinan, menghancurkan sistem sosial pada masyarakat.

Kota Ambon sebagai kota Provinsi sekaligus pusat ekonomi Provinsi Maluku yang di dalamnya berbagai macam etnis, agama dan adat yang multikultural. Kerukunan umat beragama Kota Ambon penting untuk dibangun kembali, melalui media kearifan lokal atau adat. Masyarakat Kota Ambon mengenal slogan-slogan kearifan lokal yang dapat merajut dan menciptakan kerukunan.

\section{Adat, Kerukunan dan al-Maslahah al-‘Ammah}

Adat dalam konteks hukum Pancasila melalui Peraturan Daerah Provinsi Maluku No 14 Tahun 2005 Tentang Penetapan Kembali sebagai Kesatuan Masyarakat Hukum Adat Dalam Wilayah Pemerintahan Provinsi Maluku. Sedangkan pada tingkat Nasional, Undang-Undang Dasar Tahun 1945, Pasal 18 B ayat (2) menggariskan bahwa: "Negara mengakui dan menghormati kesatuan-kesatuan masyarakat hukum adat beserta hak-hak tradisionalnya sepanjang masih hidup dan sesuai dengan perkembangan masyarakat dan prinsip Negara Kesatuan Republik Indonesia yang diatur dalam Undang-Undang”. Ketentuan Pasal 18 B sebagaimana dianut pada pertimbangan mengingat daripada Peraturan Daerah Nomor 14 Tahun 2005, mengindikasikan bahwa proses pemilihan Kepala Pemerintahan Negeri Adat, selaras

\footnotetext{
${ }^{1}$ M. Irfan Riyadi dan Basuki, Membangun Inklusifisme Faham Keagamaan (Ponorogo: STAIN Ponorogo Press, 2009), h. 1.

${ }^{2}$ Rustam Kastor, Selamatkan Maluku Dari Ancaman Idiologi Separatis RMS (Cet. I; Jakarta: PT. Candi Cipta Paramuda, 2004), h. 12.
} 


\section{Tahkím}

Vol. XIV, No. 1, Juni 2018

dengan ajaran demokrasi Pancasila. Ketentuan-ketentuan ini kontekstual dengan hukum dan demokrasi Pancasila, pada negeri adat di Ambon (Maluku).

Kerukunan secara etimologi pada awalnya terambil dari bahasa Arab, yaitu: ruknun ( ), yang berarti tiang, tempok atau bisa diartikan dengan pondasi. Kata jamak ruknun yaitu arkān ( ), bermakna "suatu bangunan yang terdiri dari berbagai unsur."3 Dari kata arkān diproleh pengertian bahwa, kerukunan merupakan sebuah kesatuan yang terdiri dari berbagai unsur yang saling berlainan dan dari setiap unsur tersebut saling mengikat dan menguatkan. ${ }^{4}$ Kesatuan tidak akan terwujud apabila salah satunya tidak saling menguatkan.

Kamus Besar Bahasa Indonesia yang diterbitkan oleh Departemen Pendidikan dan Kebudayaan, menyebutkan bahwa istilah "kerukunan" 5 diartikan sebagai "hidup bersama dalam masyarakat dengan "kesatuan hati" dan "bersepakat" untuk tidak menciptakan perselisihan dan pertengkaran". Kerukunan adalah istilah yang dipenuhi oleh muatan makna "baik" dan "damai". Intinya, hidup bersama dalam masyarakat dengan "kesatuan hati" dan "bersepakat" untuk tidak menciptakan perselisihan dan pertengkaran.

Umat beragama pada saat ini dihadapkan dengan adanya intoleran yang menimbulkan konflik antarumat beragama, potensi perselisihan yang berujung pada konflik sangat terbuka lebar. Samuel P. Huntington menyatakan bahwa, ${ }^{6}$ ada dua unsur pembatas terjadinya sebuah perselisihan diakibatkan oleh. Pertama unsur objektif, yaitu bahasa, sejarah peradaban, agama, adat istiadat, dan lembaga-lembaga. Kedua unsur subjektif, yaitu identifikasi dari diri manusia. Menurutnya, perbedaan antara pembatas itu adalah fakta dan penting. Pada hakikatnya secara alamiah manusia telah berbeda antara satu dengan yang lain.

Manusia secara fitrahnya tidak akan bisa hidup dengan kesendiriannya, ia akan mengalami gangguan kejiwaan apabila memaksakan hidup dengan membatasi diri dari manusia lain selama hidupnya. Karena manusia secara kodratnya membutuhkan orang lain dalam kehidupannya. Maka dari itu, agama mengajarkan kepada setiap pemeluknya untuk hidup saling berdampingan, dan saling tolong-menolong tanpa batas status sosial dan diskriminasi ajaran agama. Dalam kehidupan beragama di tengah

${ }^{3}$ Ibn Manzūr, Lisān al- 'Arab, Juz. XV (Cet. 3; Beirūt: Dār al-Sadîr, 1414 H), h. 123. Lihat pula Departemen Pendidikan dan Kebudayaan RI, Kamus Besar Bahasa Indonesia (Jakarta: PN Balai Pustaka, 1988), h. 658.

${ }^{4}$ Budhi Munawar Rahman, Islam Pluralis; Wacana Keseteraan Kaum Beriman (Jakarta: Paramadhina, 2002), h. 84.

${ }^{5}$ Kementerian Pendidikan dan Kebudayaan RI, Kamus Besar Bahasa Indonesia (Jakarta: Balai Pustaka, 2015), h. 850.

${ }^{6}$ Samuel P. Huntington, "Benturan Antar Peradaban, Masa Depan Politik Dunia?" dalam Jurnal Ulumul Quran, No. 5, Vol. IV, Tahun 1993, h. 12. 


\section{Tahkím}

Vol. XIV, No. 1, Juni 2018

masyarakat plural dan multikultural, salah satu hal penting yang perlu dibangun yaitu asas kebebasan/kemerdekaan (al-Hurriyah).

A. Djazuli mengartikan al-Hurriyah dengan kemerdekaan ini meliputi kemerdekaan berfikir, bertindak, dan pula kemerdekaan beragama. ${ }^{7}$ Kebebasan atau kemerdekaan dalam menjalankan keagamaan ini, agama Islam mengajarkan kepada manusia untuk melaksankan keagamaan tidak dengan paksaan atau tekanan dari pihak luar, dan tidak memaksakan kepada orang lain untuk memeluk agama Islam. Firman Allah swt. QS al-Baqarah/2: 256.

Terjemahnya:

$$
\text { لا إِكْراهِ فِي الدِّيِنِ }
$$

'Tidak ada paksaan dalam (menganut) agama (Islam)..."8

Dari ayat di atas, M. Quraish Shihab memetakan empat prinsip dalam memahami setiap perbedaan keragaman dalam kebebasan beragama yaitu: ${ }^{9}$

a. Senantiasa melakukan diskusi dan menjauhkan sikap paksaan, tekanan, intimidasi, kekerasan, rasis dalam pergaulan dengan pemeluk agama lain;

b. Islam memandang Ahli Kitab memiliki persamaan akidah, yaitu sama-sama agama samawi yang berasal dari Sang Khalik. Islam mengakui kebenaran dan kesucian Kitab Taurat, Zabur, dan Injil dalam keadaan asli;

c. Islam senantiasa menjalin hubungan persahabatan terhadap penganut agama-agama lain, sebagai makhluk manusia yang memakmurkan bumi ini;

d. Pendekatan dengan menggunakan akal sehat terhadap pemeluk agama-agama lain untuk hidup berdampingan, tidak melakukan pengrusakan, aktif melakukan dialog dan diskusi yang baik, sikap sportif dan fair.

Secara psikologis, sosiologis dan teologis tokoh agama sangat kuat pengaruhnya di tengah masyarakat. Peran tokoh agama tidak hanya terbatas pada bidang spiritual dan ibadah bidang privat, namun pada bidang publik dan sosial yang cakupannya lebih luas. Peran tokoh agama tidak hanya sebatas sebagai mediator hukum dan doktrin keagamaan, tetapi sebagai agen perubahan sosial masyarakat (social change) dan pranata budaya (cultural broker). Sebagaimana yang diungkapkan oleh Karel A. Steenbrink, ${ }^{10}$ bahwa tokoh agama walaupun ruang lingkupnya kecil dan pengaruhnya terbatas secara teritorial, namun masih diakui oleh masyarakat beragama sebagai ikon atau figur yang ideal dalam kedudukan kultural dan struktural yang tinggi.

${ }^{7}$ A. Djazuli, Fiqh Siyasah (Jakarta: Prenada Media. 2003), h. 197.

${ }^{8}$ Kementerian Agama RI, Al-Qur'an dan Terjemahnya (Jakarta: Direktorat Bimbingan Masyarakat Islam Direktorat Urusan Agama Islam dan Pembinaan Syari'ah, P.T. Karya Azzahra Mandiri, 2014), h. 42.

${ }^{9}$ M. Quraish Shihab, Tafsir al-Misbah, Pesan, Kesan, dan Keserasian Alquran, Juz VI dan X (Jakarta: Lentera Hati, 2002), h. 160-162 dan 513-515.

${ }^{10}$ Karel A. Steenbrink, Pesantren, Madrasah, Sekolah (Jakarta: LP3ES, 1986), h. 109. 


\section{Tahkím}

Vol. XIV, No. 1, Juni 2018

Rasulullah saw. diproklamirkan oleh Alquran sebagai uswatun al-hasanah dengan predikat tertinggi akhlak yang terpuji. Beliau telah memberikan batasan secara nyata dari seluruh pranata sosial kehidupan dalam masyarakat, salah satu diantaranya adalah bagaimana menciptakan masyarakat yang hidup dengan rukun, toleran, dan damai dalam kehidupan umat beragama.

Al-Sya ibî dengan sangat indah dan menawan mendeskripsikan kerukuna umat beragama ini, menurutnya, ajaran agama tidak hanya memuat ajaran yang menekankan pada bidang ibadah semata atau ta'abudiyah, namun lebih jauh dari itu ajaran agama membawa misi kemaslahatan bagi kehidupan manusia (al-maşlahah al-'ammah). ${ }^{11}$ Penetapan pada nilai al-ukhuwah insāniyah atau persaudaraan kemanusiaan yang merupakan pedoman hubungan antarkelompok ,agama, dan lainnya dalam masalah multikultural, multiagama, multibahasa, dan pluralitas dalam konteks interaksi sosial, karena Alquran telah menetapkan semua perbedaan ras, suku, budaya, dan agama merupakan ketetapan Allah swt. (takdir).

Kehidupan umat beragama saat ini, di tengah masyarakat plural dan multikultural. Alwi Shihab, ${ }^{12}$ memberikan solusi yaitu dengan cara membuka dialog antarumat beragama dan mempersiapkan diri untuk melakukan diskusi dengan umat agama lain yang berbeda pandangan tentang kenyataan hidup. Dialog ini dimaksudkan untuk saling mengenal, pengertian, dan saling pengertian tentang agama mitra dialog. Dengan dialog akan memperkaya wawasan kedua belah pihak dalam rangka mencari titik-titik persamaan yang dapat dijadikan landasan hidup dalam suatu masyarakat, yaitu toleran dan pluralitas yang multikultural.

\section{Efektifitas Adat Dalam Menciptakan Kerukunan}

\section{Nilai Pela dan Gandong}

Secara filosofis pela dan gandong bukan sekedar hubungan atau ikatan, tetapi dimaknai sebagai ikatan geneologis. Lebih dari pada itu merupakan ikatan sosial yang melintasi batas-batas kesukuan maupun agama (Islam atau Kristen) dari tiap-tiap desa/negeri yang memiliki pela. Pela dan gandong pada hakikatnya mencirikan wacana kontekstual (local genius), yang memberi keyakinan dan petunjuk tentang masyarakat adat sebagai keadaan yang bersifat antropologis dan sosio-religius. Daya eksis masyarakat sebagai rumpun budaya dan merupakan bukti autentik bahwa imajinasi adatis dan religius yang mampu memproduksi serta menghadirkan identitas masyarakat Ambon untuk memahami dan mentransformasi eksistensi sejarahnya yang

${ }^{11}$ Abū Ishāq al-Syātibî, al-Muwāfaqāt fî Ushūl al-Fiqh, Jilid. I (Mesir: Maktabah al-Tijāriyah alKubrā, t.th.), h. 3-23. 1999), h. 43.

${ }^{12}$ Alwi Shihab, Islam Inklusif: Menuju Sikap Terbuka dalam Beragama (Bandung: Mizan, 


\section{Tahkím}

Vol. XIV, No. 1, Juni 2018

khas. Bahkan dipertegas oleh Watloly sebagai pembentukan kepribadian diri sebagai brother and sister ${ }^{13}$ dan hubungan me and my self bukan me and you. ${ }^{14}$

Pela dan gandong antarumat beragama (Islam-Kristen) efektif dalam kegiatankegiatan yang bersifat sosial dan dapat berjalan bersama. ${ }^{15}$ Dalam perjalanannya, masyarakat yang semakin pluralis dan multikultural terdapat berbagai etnis, bahasa dan adat yang lain masuk dan membaur menjadi satu di Ambon. Konsep pela dan gandong dibutuhkan inovasi dan peremajaan kembali. ${ }^{16}$ Artinya pela dan gandong pada awalnya hanya sebatas dua atau tiga negeri yang mempunyai ikatan kekerabatan atau hubungan, untuk masa ini dapat dibuat atau direkayasa pela dan gandong dengan konsep yang baru. ${ }^{17}$ Hubungan kekerabatan dalam bingkai Pela dan gandong bisa pula dengan masyarakat yang bukan asli penduduk Ambon.

Konsep pela dan gandong menurut Ketua GPM terdapat kelemahan, di dalamnya hanya rukun di antara mereka yang mempunyai ikatan atau hubungan pela dan gandong itu. Sedangkan dengan masyarakat atau daerah lain tidak. ${ }^{18}$ Seperti para pendatang dan pribumi yang tidak memiliki ikatan pela dan gandong. Maka untuk itu, agar dapat efektif konsep pela dan gandong diperlukan inovasi baru untuk membuka ruang pada daerah lain atau suku lain (membuka ruang dengan pendatang), untuk membuat ikatan pela atau gandong dengan masyarakat atau suku lain. Karena pada hakikatnya konsep pela dan gandong merupakan ikatan persaudaraan sesama manusia, sedangkan gandong ikatan adik dan kakak dari rahim yang sama. Dapat dipahami semua makhluk yang bernama manusia itu semuanya bersaudara dan dari satu ayah (nabi Adam) dan satu rahim (Siti Hawa).

\section{Transformasi Nilai Pela dan Gandong dalam Konteks Kekinian}

Perekat-perekat dalam menciptakan kerukunan umat beragama yang berbasis adat pela dan gandong, harus dikontekstualisasikan seiring dengan tantangan masyarakat yang semakin berkembang, dan tantangan masyarakat yang semakin plural dan multikultural. Kearifan lokal seperti pela dan gandong merupakan kontrak hubungan atau ikatan para nenek-moyang saat itu, untuk menjadikan negeri-negeri

\footnotetext{
${ }^{13}$ Aholiab Watloly, Maluku Baru: Bangkitnya Mesin Eksistensi Anak Negeri (Yogyakarta: Kanisius, 2005), h. 208.

${ }^{14}$ Aholiab Watloly, Ketua Pusat Studi Pancasila Unpatti Ambon, hasil wawancara di FISIP Unpatti, Ambon 11 April 2018.

${ }^{15}$ Abdul Manan Latuconsina, Sekretaris MUI Kota Ambon, hasil wawancara di kantornya, Ambon 09 Januari 2018.

${ }^{16}$ Kata peremajaan ini istilah yang diungkapkan oleh Sekretaris MUI Kota Ambon, ketika peneliti melakukan wawancara di kantornya, Ambon 09 Januari 2018.

${ }^{17}$ Abdul Manan Latuconsina, Sekretaris MUI Kota Ambon, hasil wawancara di kantornya, Ambon 09 Januari 2018.

${ }^{18}$ A.J.S. Werinussa, Ketua Gereja Protestan Maluku, hasil wawancara di kantornya, Ambon 07 Februari 2018
} 


\section{Tahkím}

Vol. XIV, No. 1, Juni 2018

pada waktu itu menjadi saudara dalam ikatan atau hubungan yang dilakukan melalui proses-proses yang beragam. Ada yang melakukan ritual minum darah atau sumpah setia. Cakupannya masih sangat terbatas, pada kebutuhan dan tantangan masyarakat yang homogen dan terbatas pada dua atau tiga negeri adat. Sedangkan gandong merupakan ikatan persaudaraan karena adanya hubungan geneologis antara dua atau beberapa buah negeri adat. Kearifan lokal ini ke depan, memiliki tantangan yang cukup besar, karena perkembangan masyarakat yang semakin plural dan kompleks serta tingkat dinamika sosial dan ekonomi yang semakin tinggi.

Faktor yang mendasar kearifan lokal pela dan gandong sampai saat ini masih tetap hidup dan menjadi kekuatan perekat kerukunan ditengah umat beragama, karena mengandung nilai-nilai kemanusiaan dan persaudaraan yang luhur. Karena itu, transformasi nilai-nilai kemanusiaan dan persaudaraan dalam budaya masyarakat Kota Ambon yang semakin plural dan multikultural merupakan suatu kebutuhan. Transformasi kearifan lokal pela dan gandong perlu dilakukan agar tetap kontekstual dan tidak kehilangan perannya di dalam umat beragama masyaraka. Faktanya masyarakat Kota Ambon untuk saat ini, adalah masyarakat plural dan multikultural yang memiliki sentuhan nilai budaya yang kompleks.

Kaum pendatang seperti Jawa, Bugis, Makassar, Sumatra, Buton dan lainnya, dewasa ini membuat masyarakat menjadi tersegmentasi bukan hanya pada masalah agama tetapi pula pada masalah etnis. Karena itu agar nilai kearifan lokal pela dan gandong dapat ditransformasikan menjadi nilai kekuatan perekat dan kekuatan menciptakan kerukunan dalam masyarakat yang multikultural, menurut Abd. Rauf, masyarakat setempat (penduduk asli) perlu mensosialisasikannya kepada pendatang. Pendatang pun harus mampu menyerap adat setempat seperti 'take and give. ${ }^{19}$ Agar masyarakat tidak cenderung akan hanya tunduk dan patuh pada aturan-aturan formal. Untuk menghindari kondisi seperti itu, rekayasa kearifan lokal dengan mentransformasikan nilai-nilai pela dan gandong merupakan suatu kebutuhan untuk masa depan umat beragama masyarakat yang plural dan multikultural.

Agama dalam ajarannya harus dipahami oleh pemeluknya sebagai kekuatan etis (akhlāq al-karîmah), yaitu rahmat bagi kemanusiaan yang universal. Pemahaman ini dalam aplikasi ajaran agamanya akan mampu mengakomodasi kehidupan yang plural dan multikulural, karena pada hakikatnya konsep agama sebagai rahmat bagi seluruh makhluk dan alam. Alquran mengakui dan membenarkan kehidupan manusia yang plural dan multikultural sebagai hasil cipta Allah swt. plural dan multikultural bukan

\footnotetext{
${ }^{19}$ Abdul Rauf, Dosen IAIN Ambon, Anggota FKUB Bidang Kerukunan, dan Anggota MUI Maluku Bidang Fatwa), hasil wawancara di kediamannya, Ambon 18 Februari 2018.
} 


\section{Tahkím}

Vol. XIV, No. 1, Juni 2018

kehendak dan pilihan manusia, namun ketentuan yang ditakdirkan Allah swt. sebagai manusia yang berbeda-beda. QS al-Hujurat/49: $13 .^{20}$

Pemahaman keagamaan yang mengakui dan menerima perbedaan dan keragaman dalam masyarakat plural dan multikultural akan mampu membangun dan menciptakan kerukunan yang ideal pada umat beragama. Pengakuan dan menerima atau toleran pada realitas kehidupan umat beragama yang plural dan multikultural yang tidak terbatas pada pluralitas etnis dan agama, tetapi dalam konteks yang luas yaitu mengakui dan menerima pada identitas-identitas kearifan lokal yang telah tumbuh berkembang dan melekat pada masyarakat tersebut merupakan sebuah keniscayaan.

\section{Nilai Siwa Lima dan Wih\{dah al-ummah}

Hubungan kerukunan antara komunitas yang secara umum dengan para pendatang. Menurut Watloly, ${ }^{21}$ para pendatang merupakan nutrisi dalam tubuh yang memberi kekuatan dan mempertegas dalam proses integrasi di Kota Ambon dan Maluku. Walaupun pada prinsipnya secara turun temurun mereka tidak termasuk dalam unsur-unsur kearifan lokal Siwa Lima. Integrasi kearifan lokal Siwa Lima sesungguhnya inheren dan relevan dalam berbagai konteks kehidupan di semua lapisan masyarakat, agama dan etnis.

Para pendatang yang telah berketurunan di Kota Ambon sejatinya diakomodir untuk mendukung proses integrasi secara umum antar berbagai lintas komunitas. Secara informal, integrasi itu telah berjalan lama, melalui akulturasi perkawinan dan agama sehingga kompleksitas persoalan integrasi itu tidak dapat dihindarkan. Untuk itu, muncul kesadaran untuk masuk dalam lingkaran kearifan Siwa Lima. Hal ini membantu dalam proses penyadaran kembali akan keanekaragaman manusia dan segala perspektifnya agar mereka saling membantu dalam menciptakan kerukunan dan dalam pembangunan pemerintah. Dengan demikian, prinsip Siwa Lima akan tertanam dalam setiap jiwa masyarakat secara umum dalam berbagai budaya yang beragam yang dilakonkan secara integratif, yaitu mengakarnya perbedaan antar berbagai suku, agama, dan etnis di Kota Ambon.

Nilai Siwa Lima dalam bentuk kebersamaan dan tanggung jawab bersama adalah modal dasar untuk membangun dan menciptakan peradaban umat beragama, dan untuk mempertahankan eksistensi pribadi dan jamaah sebagai bagian dari masyarakat bangsa Indonesia. Masyarakat Kota Ambon, harus siap dengan pluralisme, menghargai perbedaan dan mencintai sesama manusia, dan mengakui setiap hak dan kedudukan manusia di hadapan Tuhannya. Secara prinsip masyarakat Kota Ambon dan Provinsi

\footnotetext{
${ }^{20}$ Kementerian Agama RI, op.cit., h. 516.

${ }^{21}$ Aholiab Watloly, Ketua Pusat Studi Pancasila Unpatti Ambon, hasil wawancara di FISIP Unpatti, Ambon 11 April 2018.
} 


\section{Tahbím}

Vol. XIV, No. 1, Juni 2018

Maluku diperlukan memiliki desain kearifan lokal agar dapat terlibat secara langsung dalam proses pembangunan kerukunan. Yaitu:

1. Mendesain kesepakatan adat untuk membangun integritas kemalukuan dalam segala aspek sesuai dengan nilai Siwa Lima.

2. Memegang teguh religiusitas keagamaan tanpa melepaskan simbol-simbol kearifan lokal akan identitas masyarakat Ambon.

3. Mengutamakan hidup dalam perbedaan, karena anak negeri Ambon satu keluarga, Salam-Sarani yang terintegrasi dalam Siwa Lima.

4. Menumbuhkembangkan pemahaman tentang hubungan persaudaraan, kerukunan antarumat beragama.

\section{Nilai Ale Rasa Beta Rasa dan Kemaslahatan Umat}

Nilai-nilai yang terkandung dalam ale rasa beta rasa sebagai slogan vokal adat, mengandung makna yang sangat dalam untuk saling merasakan, saling membutuhkan, saling melindungi satu sama lain diantara anak negeri Ambon. Ale rasa beta rasa bukan saja 'kamu' dan 'saya' saling merasakan, namun lebih dari itu sebagaimana yang diungkapkan oleh Aholiab Watloly, ${ }^{22}$ bahwa makna filosofi ale rasa beta rasa dimaknai dengan ( $I$ and $m e$ ) saya dan saya. Dapat dipahami bahwa saya dan kamu sama, sama-sama satu tubuh yang tidak terpisahkan, ketika ada bagian tubuh yang sakit maka bagian tubuh yang lain pasti akan merasakan. Ini merupakan gambaran nilai adat yang terkandung pada slogan lokal ale rasa beta rasa (apa yang kamu rasakan, saya juga merasakan).

Ajaran dan aturan hukum Islam dalam sejarahnya tidak pernah mengabaikan kemaslahatan-kemaslahatan keutuhan dan keseimbangan kehidupan umat manusia, dan selalu menghilangkan kemudaratan-kemudaratan manusia. Hal ini bagaimana hubungan umat beragama pada awal-awal Islam hadir ditengah umat manusia, Islam yang di emban Rasulullah saw. beliau sendiri pelaku utama yang meletakkan dasardasar Islam yang sarat dengan nuansa lokal atau adat dan tradisi lokal.

Demi terciptanya hubungan timbal balik yang harmonis, rukun, dan toleran. Dalam tafsir QS al-Imran/3:17. Rasulullah saw. diriwayatkan beliau pernah menjenguk seorang budak Yahudi yang sedang sakit, sedangkan ayah si budak itu berada disamping kepalanya. Dengan yang sangat menginginkan keimaman si budak itu, Rasulullah saw. mengajaknya masuk Islam: "Wahai fulan, ucapkan; lā ilāha illallāh (tiada tuhan selain Allah)". Budak itu tidak langsung menjawab, ia justru memandangi ayahnya seolah-oleh meminta pertimbangan. Sedangkan ayahnya hanya diam. Rasulullah saw. mengulanginya, dan budak itu kembali menengok ayahnya. Kemudian ayahnya berkata: “ikutilah Abu Qasim”, maka di hadapan Rasulullah saw., budak itu

\footnotetext{
${ }^{22}$ Aholiab Watloly, Ketua Pusat Studi Pancasila Unpatti Ambon, hasil wawancara di FISIP Unpatti, Ambon 11 April 2018.
} 


\section{Tahkím}

Vol. XIV, No. 1, Juni 2018

mengucapkan: اشهذ ان لااله الا الله وانك رسول الله (aku bersaksi bahwa tiada tuhan selain Allah dan sesungguhnya engkau adalah utusan Allah). Rasulullah saw. keluar dan berkata: "segala puji bagi Allah yang telah mengeluarkannya dari neraka melaluiku." 23 Riwayat kisah hadis ini pula terdapat dalam sunan Ibnu Hibban.

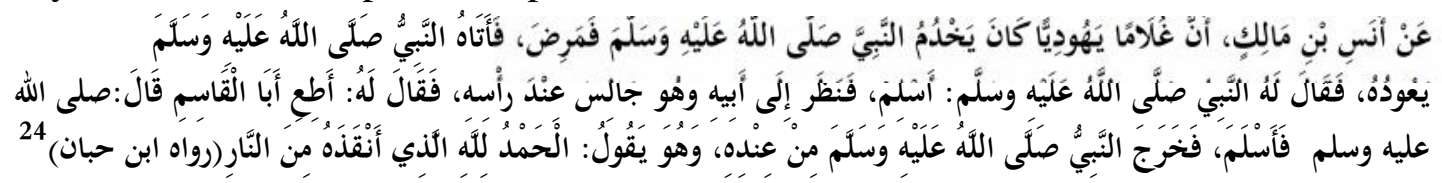
Artinya:

'Dari Anas bin Malik ra. Bahwa seorang anak Yahdi mengalami sakit, kemudian Rasulullah saw. datang menjenguknya, lalu duduk di sebelah kepalanya dan bersabda kepadanya: "Masuklah Islam, kemudian anak tersebut memadang ayahnya sementara ayahnya berada di sebelah kepalanya. Kemudian ayahnya berkata: "Taatilah Abu al-Qasim. Kemudian anak tersebut masuk Islam. Lalu Rasulullah saw. mengucapkan: "Segala puji bagi Allah yang telah menyelamatkannya dari api neraka."

Riwayat lain yang selaras dengan nilai ale rasa beta rasa, yaitu sahabat Abdullah bin Umar yang diriwayatkan oleh Mujahid: “Aku sedang berada di kediaman Ibnu Umar, ketika itu budaknya sedang menguliti sesekor domba, maka Abdullah berkata kepada budakny: "Jika engkau telah selesai, dahulukanlah tetangga kita si Yahudi,' lalu seorang lelaki berkata: “orang Yahudi? Semoga Allah menunjukkan kebaikan kepadamu,' Ibnu Umar berkata: “Aku mendengar Nabi mewasiatkan tetangga, hingga yang berwatak keras atau lembut, bahwa tetangga hampir saja berhak mendapat waris.

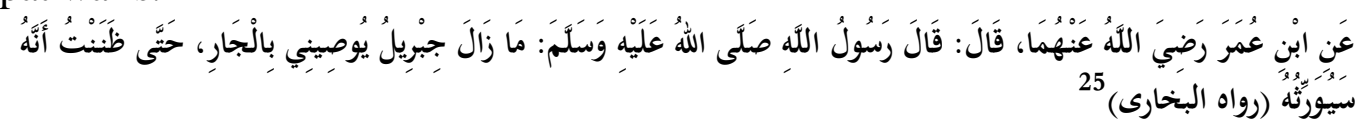

Artinya:

Dari Abdullah bin Umar ra berkata: "Telah bersabda Rasulullah saw. Jibril masih berwasiat kepadaku (Rasulullah saw.) terhadap tetangga, seakan-akan hamper (tetangga) berhak mendapatkan bagian waris."

Dua riwayat di atas, jelas nampak sekali bagaimana kepedulian Rasulullah saw., dan sahabat Ibnu Umar kepada umat yang berbeda agama. Interaksi hubungan sosial kemasyarakatan yang berbeda agama diutamakan dalam Islam agar terwujud kemaslahatan umat yang saling menyayangi dan mengasihi. Tujuan Syariat Islam itu untuk mendatangkan kemaslahatan umat secara keseluruhan, hidup dalam kerukunan

\footnotetext{
${ }^{23}$ Abū al-Fidā Ismāil bin Umar bin Katsir, Tafsir Ibn Katsir, Juz. II (Riyād: Dār al-Taibah, 1999), h. 26.

${ }^{24}$ Muhammad bin Hibbān bin Ahmad Abū Hātim al-Tamimî al-Bastiyyu, Sahîh $\{$ Ibnu Hibbān, Juz. XI (Bairūt: Muassasah al-Risālah, 1993), h. 242.

${ }^{25}$ Abî Abdullah Muhammad bin Ismāil al-Bukhārî, al-Jāmi’ al- ahîh, Juz. VI (Beirut, Dar alKutub al-Ilmiyyah, 2992), h. 94.
} 


\section{Tahkím}

Vol. XIV, No. 1, Juni 2018

tanpa perselisihan. Kemaslahatan ini dimaknai dengan kemaslahatan al-'a>mmah. Rasulullah saw. merupakan seorang Nabi pembawa rahmat bagi seluruh makhluk. QS al-Anbiya>/21:107.

Terjemahnya:

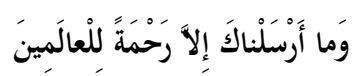

Dan Kami tidak mengutus engkau (Muhammad) melainkan untuk (menjadi) rahmat bagi seluruh alam. ${ }^{26}$

Nilai ale rasa beta rasa menjadi nilai diri atau akhlak al-karimah perilaku moral baik, perilaku moral yang baik merupakan moral di dalam hubungan antarumat beragama. lahir darinya rasa kasih sayang untuk menyayangi seluruh umat manusia dan alam raya.

\section{Nilai Katong Bamua Basudara dan Ukhuwah Insaniyah}

Persaudaraan dalam syariat Islam telah ditetapkan bahwa semua manusia berasal dari satu bapak (nabi Adam) dan satu ibu (Siti Hawa). Satu jenis keturunan ini terjalin dalam hubungan persaudaraan. Allah swt telah menegaskan dalam QS alNisa/4:1.

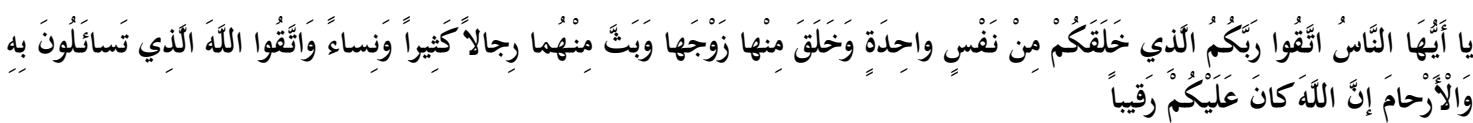

Terjemahnya:

Wahai manusia Bertakwalah kepada Tuhamnu yang telah menciptakan kamu dari diri yang satu (Adam), dan (Allah) menciptakan pasangan (Hawa) dari (diri) nya; dan dari keduanya Allah memperkembangbiakkan laki-laki dan perempuan yang banyak. Bertakwalah kepada Allah yang dengan nama-Nya kamu saling meminta, dan (peliharalah) hubungan kekeluargaan. Sesungguhnya Allah selalu menjaga dan mengawasimu.' 27

Penafsiran ayat di atas, menurut Abu Ja'far al-Tabari dalam tafsirnya, ${ }^{28}$ bahwa adanya perintah dari Allah swt. untuk menjaga hubungan baik dengan umat manusia, dan larangan untuk merusak hubungan tersebut. Lanjutnya umat manusia diperintahkan untuk saling melindungi dan memberikan ketentraman kepada orang lain. Saling menasehati, dan tidak dibenarkan yang kuat menindas yang lemah, dan tidak menciptakan kemudaratan untuk saudaranya sesama manusia.

Kata al-Arhām (hubungan kekelurgaan) sebagaimana menurut al-Qurtubî, ${ }^{29}$ yaitu larangan untuk memutus hubungan kemanusiaan. Dari sini dipahami adanya perintah untuk menjalin dan menjaga sekaligus menciptakan hubungan dengan manusia yang

\footnotetext{
${ }^{26}$ Kementerian Agama RI, op.cit., h. 331.

${ }^{27}$ Ibid., h. 77.

${ }^{28}$ Muhammad bin Jarîr bin Yazîd bin Katsîr bin Gālib al-Amalî Abū Ja'far al-Tabarî, Tafsîr alTabarî Jāmi'i al-Bayān 'an Ta'wil al-Qur'ān, Juz VI (Cet. I; Dār Hijrah, 2001), h. 339.

${ }^{29}$ Al-Qurtubî, Jāmi'u al-Ahkām al-Qur'ān Tafsîr al-Qurtubî̀, Jilid. V (Al-Qāhirah: Dār al-Kutub al-Mi riyah, 1964), h. 2.
} 


\section{Tahkím}

Vol. XIV, No. 1, Juni 2018

belum dikenal sebelumnya. Karena pada awalnya manusia itu dari umat yang satu yang tidak dipisahkan atau dicerai-beraikan. Kemudian dalam ayat yang lain Allah swt berfirman. QS al-Baqarah/2:213.

Terjemahnya:

$$
\text { كَانَ النَّاس أُمَّةً واحِدَةُ }
$$

'Manusia itu (dahulunya) satu umat.' 30

Dari kedua ayat di atas, dipahami bahwa Alquran memerintahkan kepada manusia agar menjalin dan menjaga hubungan persaudaraan (silaturahim) sesama karib kerabat, seagama, dan hubungan yang bersifat kemanusiaan secara umum yang berbeda agama. Yang diawali dengan kalimat seruan yā ayyuha al-nās (hai sekalian manusia) mempertegaskan vokal panggilan kepada seluruh umat manusia, dengan menyebut 'jiwa yang satu' yang terdiri dari laki-laki dan wanita yang berasal dari nabi Adam as. dan satu gandong (satu rahim) dari Siti Hawa. Hal ini tentunya kata al-arhām yaitu hubungan persaudraan silaturahim antarumat manusia memiliki maksud dan tujuan yang agung.

Persaudaraan itu mencakup antarumat manusia, bukan antarseagama atau etnis tertentu. Hal ini menunjukkan pentingnya persatuan dan kesatuan seluruh umat manusia. Islam telah mempraktekkan sistim persaudaraan yang luhur, dan menegakkannya di atas asas sebuah masyarakat madani yang rukun dan toleran. Kontruksi masyarakat madani, rukun dan toleran itu ditemukan di Madinah setelah Rasulullah saw. dan para sahabat Muhajirin berhijrah dari Mekkah ke Madinah. Di bawah naungan syariat Islam, lenyapnya api permusuhan yang menyebabkan konflik berkepanjangan antara suku Aus dan Khazraj. Persuadaran yang begitu indah antara kaum Muhajirin (pendatang) dengan kaum Ansar (penduduk lokal).

Persaudaraan dalam syariat Islam tidak pernah membuat garis perbedaan jenis, ras, warna kulit, suku, etnis, agama, dan status sosial. Namun persaudaraan yang menyatukan semua status tersebut menjadi umat yang satu (ummatan wa> h\{idah). Begitu pentingnya persaudaraan dalam Islam, seorang Muslim tidak dibenarkan memutus dan enggan menjalin hubungan silaturahim hanya karena beda agama. Rasulullah saw. ketika menjawab pertanyaan Asma binti Abu Bakar yang menanyakan tentang ibunya (Qutaylah binti Abdul Uza) ${ }^{31}$ yang datang ke Madinah dalam keadaan musyrik. Asma' berkata: Wahai Rasulullah, ibuku telah datang ke Madinah, apakah aku harus bersilaturahim kepdanya?' Nabi bersabda: "Bersilaturahimlah kepada ibumu."

\footnotetext{
${ }^{30}$ Kementerian Agama RI, op.cit., h. 33.

${ }^{31}$ Qutaylah binti Abdul Uza merupakan istri Abu Bakar yang telah diceraikannya karena enggan masuk Islam.
} 


\section{Tahkím}

Vol. XIV, No. 1, Juni 2018

Dalam kesempatan lain, Qutaylah binti Abdul Uza datang membawa hadiah untuk 'Asma berupa makanan, namun 'Asma enggan menerima pemberian ibunya, bahkan ia melarang ibunya untuk sekedar masuk rumahnya. Kemudian Aisyah binti Abu Bakar saudara seayah-nya, ${ }^{32}$ bertanya kepada Rasulullah saw. perihal itu. Maka turunlah ayat: QS al-Mumtahanah/60:8.

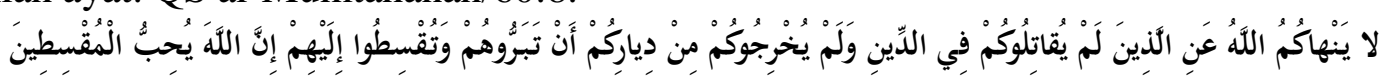

Terjemahnya:

'Allah tidak melarang kamu berbuat baik dan berlaku adil terhadap orang-orang yang tidak memerangimu dalam urusan agama dan tidak mengusir kamu dari kampong halamanmu. Sesungguhnya Allah mencintai orang-orang yang berlaku adil. $^{33}$

Sayyid Quthub ${ }^{34}$ berkomentar dalam menafsirkan ayat di atas, bahwa Islam adalah agama damai. Ajaran Islam ialah satu sistem yang bertujuan menaungi seluruh alam dengan naungannya yang berupa kedamaian dan cinta kasih, dan semua manusia dihimpun di bawah panji Ilahi dalam kedudukan sebagai saudara-saudara yang saling kenal-mengenal dan cintai-mencintai. Islam tidak menginginkan terjadinya permusuhan dan tidak berusaha untuk melakukannya, bahkan dalam keadaan bermusuhan, Islam tetap memelihara dalam jiwa faktor-faktor keharmonisan hubungan melalui tingkah laku yang jujur dan berlaku adil.

Kata (تبروهم) tabarrūhum terambil dari kata ( ) birr yang berarti kebajikan yang luas. ${ }^{35}$ Salah satu nama Allah swt. adalah al-Birr. Ini merupakan demikian luas kebajikan-Nya. Dengan menggunakan kata tersebut oleh ayat di atas, tercermin izin kebolehan untuk melakukan aneka kebajikan bersama dan bagi non muslim dalam konteks hubungan kemanusiaan, selama tidak membawa dampak negatif bagi umat Islam.

Berbuat baik kepada sesama manusia yang berbeda agama termasuk bagian dari hubungan yang diperintahkan, dan diketahui tidak akan berdampak negatif bagi umat Islam. Karena Allah swt. menyukai kelemahlembutan dalam segala hal dan memberi imbalan atasnya dengan apa yang tidak diberikan-Nya melalui jalan lain. Ayat di atas berlaku secara umum kapan dan di mana saja. Sebagaimana pernyataan Tāhir Ibn 'Asyūr yang dikutip oleh Quraish Shihab, ${ }^{36}$ bahwa pada masa Rasulullah saw. sekian banyak suku-suku kaum musyrik yang justru bekerjasama dengan Rasulullah sw. serta

\footnotetext{
${ }^{32}$ Aisyah adalah putri Abu Bakar dari ibu kedua yaitu Ummu Ruman yang melahirkan Aisyah dan Abdurrahman.

${ }^{33}$ Ibid., h. 550. 3544.

${ }^{34}$ Sayyid Quthub, Fî Zilāl al-Qur'ān, Juz. VI (Cet. XVII; Beirūt: Dār al-Syurūq, 1412 H), h.

${ }^{35}$ A.W. Munawwir, Kamus Al-Munawwir Arab-Indonesia (Surabaya: Pustaka Progressif, 1984), h. 74 .

${ }^{36}$ Quraish Shihab, Tafsir al-Misbah, Volume. 14, h. 169-170.
} 


\section{Tahkím}

Vol. XIV, No. 1, Juni 2018

menginginkan kemenangan beliau menghadapai suku Quraisy di Mekah. Mereka itu seperti Khuza'āh, Banî al-Hārits Ibn Ka'āb dan Muzainah.

Ayat di atas turun berkenaan dengan Asma' binti Abi Bakar tentang bolehnya menjaga hubungan dengan orang non Muslim. Diperintahkan untuk saling tolongmenolong, berbuat baik kepada mereka. ${ }^{37}$
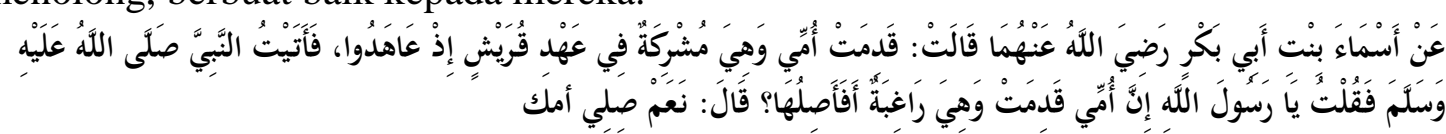

Setelah turun ayat di atas, Rasulullah saw. kemudian menyuruh Asma' untuk menerima hadiah ibunya dan memperkenankan ibunya masuk rumah. Kisah Asma dan ibunya merupakan bukti yang nyata, bagaimana syariat Islam memperhatikan hubungan persaudaraan antarumat manusia demi terwujudnya sebuah dinamika kerukunan umat beragama.

Dengan adanya nilai-nilai kearifan lokal ale rasa beta rasa, samua katong basudara, Siwa Lima, yang tujuan pokoknya adalah kemaslahatan umat manusia di alam raya ini. Nilai-nilai kearifan lokal itu lahir dari kesadaran jiwa yang bersih yang sungguh-sungguh ingin menciptakan sebuah tatanan masyarakat kultural teritorial yang rukun dan toleran.

Nilai-nilai kearifan lokal di atas yang maksud dan tujuannya untuk menciptakan kerukunan umat beragama, secara keseluruhan nilai-nilai lokal tersebut selaras dengan maksud dan tujuan syariat Islam yaitu menjaga kehidupan umat manusia dan kemaslahatan. Namun nilai lokal pela dan gandong perlu digaris bawahi, karena untuk zaman saat ini masyarakat Kota Ambon yang plural dan multikultural, nilai pela dan gandong dibutuhkan inovasi-inovasi dalam aturan main adatnya dan atau peremajaan ulang agar dapat mencakup seluruh komunitas masyarakat. Artinya ikatan hubungan pela dan gandong untuk masa sekarang dapat ber-pela dengan masyarakat luar, yaitu masyarakat pendatang. Dengan demikian pihak-pihak terkait seperti lembaga agama, tokoh agama, tokoh masyarakat, tokoh adat, dan semua lapisan masyarakat. Perlu duduk bersama mengevaluasi ulang aturan adat (zaman nenek moyang) terdapat dalam adat pela gandong yang hanya menaungi beberapa desa saja. Mensosialisasikan kepada seluruh lapisan masyarakat harus dilakukan, dan membuka ruang untuk menjalin hubungan pela dan gandong dengan masyarakat pendatang.

\section{Kesimpulan}

Efektivitas nilai-nilai adat dalam menciptakan kerukunan seperti nilai lokal Ale rasa beta rasa sebagai ekspresi saling merasakan dalam dua komunitas yang berbeda agama, dan Katong samua basudara sebagai filosofis diri masyarakat Ambon, bahwa sesungguhnya semua berasal dari bapak (nabi Adam) dan ibu (Siti Hawa) yang sama,

\footnotetext{
${ }^{37}$ Abū al-Fidā Ismaîl bin Umar bin Katsir, Tafsir Ibn Katsir, Juz VIII (Cet. I; Beirūt: Dār alKutub al-'Alamiah, 1419 H), h. 119.
} 


\section{Tahkím}

Vol. XIV, No. 1, Juni 2018

pada hakikatnya bersaudara antara Islam dan Nasrani. Sehinga nilai yang terkandung dalam hidop orang basudara atau katong samua basudara yaitu untuk mengingatkan bahwa kita bersaudara dan tidak boleh untuk berselisih antaragama, etnis; Siwa Lima merupaka slogan kearifan lokal yang telah menjadi logo Pemda Maluku, didalamnya memiliki nilai-nilai simbol yang cerdas, karena dapat memayungi seluruh lapisan masyarakat yang plural dan multikultural. Nilai dan fungsi Siwa Lima sebagai pemersatu dan perekat bagi masyarakat, sebagai bentuk kebersamaan dan tanggung jawab bersama untuk menjaga dan membangun bersama-sama kerukunan umat beragama di Kota Ambon dan Maluku; Pela gandong merupakana ikatan kekerabatan antara dua komunitas negeri atau desa berbeda agama atau seagama. Nilai dan fungsi dari pela dan gandong ini, terjalin ikatan kekerabatan yang kuat antar dua desa yang memiliki hubungan pela dan gandong ini.

Kearifan lokal yang mendatangkan kemaslahatan dan tidak membuat mudarat itu diakomodir dan bisa menjadi acuan hukum dalam syariat Islam, termasuk sloganslogan lokal adat Ambon terkait kerukunan umat beragama. Di dalamnya terkandung nilai untuk saling merasakan bagaikan satu tubuh; semua kita bersaudara dari asal yang sama; kebersamaan makan bersama; mempersatukan masyarakat multikultural dalam payung Siwa Lima; mendamaikan dua komunitas yang berselisih; dan ikatan hubungan kekerabatan yang berbeda keyakinan; slogan-slogan kearifan lokal tesebut sejauh ini belum bersebrangan dengan maksud dan tujuan syariat Islam yaitu mendatangkan kemaslahatan dan menolak kemudaratan. Tapi yang harus digaris bawahi yaitu nilai yang terkandung dalam pela dan gandong, dalam aturannya perlu revitalisasi dan inovasi yang dapat mencakup semua lapisan masyarakat untuk menciptakan kerukunan umat beragama. dari semua kearifan lokal itu pada hakikatnya bertujuan untuk menyatukan umat dalam hidup rukun dan toleran. Hal ini dapat didasarkan pada tujuan syariat Islam yaitu menjaga ummat manusia (hif l al-Ummah).

\section{DAFTAR PUSTAKA}

al-Bastiyyu, Muhammad bin Hibbān bin Ahmad Abū Hātim al-Tamimî. Sahîh Ibnu Hibbān, Juz. XI Bairūt: Muassasah al-Risālah, 1993.

Al-Bukhari, Abî Abdullah Muhammad bin Ismāil. Al-Jāmi’ al- ahîh, Juz VI, Beirut: dar al-Kutub al-Ilmiyyah, 1992.

Djazuli, A. Fiqh Siyasah, Jakarta: Prenada Media. 2003.

Departemen Pendidikan dan Kebudayaan RI, Kamus Besar Bahasa Indonesia, Jakarta: PN Balai Pustaka, 1988

Huntington, Samuel P.. "Benturan Antar Peradaban, Masa Depan Politik Dunia?" dalam Jurnal Ulumul Quran, No. 5, Vol. IV Tahun 1993.

Ibn Manzūr, Lisān al- 'Arab, Juz. XV, Cet. 3; Beirūt: Dār al-Sadîr, 1414 H. 


\section{Tahkím}

Vol. XIV, No. 1, Juni 2018

Ibn Katsir, Abū al-Fidā Ismāil bin Umar. Tafsir Ibn Katsir, Juz II, dan Juz VIII, Riyād: Dār al-Taibah, 1999

------. Tafsir Ibn Katsir, Juz VIII, Cet. I; Beirūt: Dār al-Kutub al-‘Alamiah, 1419 H

Kastor, Rustam. Selamatkan Maluku Dari Ancaman Idiologi Separatis RMS, Cet. I; Jakarta: PT. Candi Cipta Paramuda, 2004.

Kementerian Agama RI. Al-Qur'an dan Terjemahnya, Jakarta: Direktorat Bimbingan Masyarakat Islam Direktorat Urusan Agama Islam dan Pembinaan Syari'ah, P.T. Karya Azzahra Mandiri, 2014

Kementerian Pendidikan dan Kebudayaan Republik Indonesia, Kamus Besar Bahasa Indonesia , Jakarta: Balai Pustaka, 2015.

Munawwir, A.W. Kamus Al-Munawwir Arab-Indonesia, Surabaya: Pustaka Progressif, 1984.

Al-Qurtubî. Jāmi'u al-Ahkām al-Qur'ān Tafsîr al-Qurtubî, Jilid. V (Al-Qāhirah: Dār al-Kutub al-Mi riyah, 1964.

Quthub, Sayyid. Fî̀ Zilāl al-Qur'ān, Juz. VI, Cet. XVII; Beirūt: Dār al-Syurūq, 1412 H

Rahman, Budhi Munawar. Islam Pluralis; Wacana Keseteraan Kaum Beriman, Jakarta: Paramadhina, 2002.

Riyadi, M. Irfan dan Basuki. Membangun Inklusifisme Faham Keagamaan, Ponorogo: STAIN Ponorogo Press, 2009.

Shihab, M. Quraish. Tafsir al-Misbah, Pesan, Kesan, dan Keserasian Alquran, Juz VI dan X, Jakarta: Lentera Hati, 2002.

Shihab, Alwi. Islam Inklusif: Menuju Sikap Terbuka dalam Beragama, Bandung: Mizan, 1999.

Steenbrink, Karel A. Pesantren, Madrasah, Sekolah, Jakarta: LP3ES, 1986.

al-Syātibî, Abū Ishāq. al-Muwāafaqāt fî Ushūl al-Fiqh, Jilid I, Mesir: Maktabah alTijāriyah al-Kubrā, t.th.

al-Tabarî, Muhammad bin Jarîr bin Yazîd bin Katsîr bin Gālib al-Amalî Abū Ja'far. Tafsîr al-Tabarî Jāmi'i al-Bayān 'an Ta'wil al-Qur'ān, Juz VI, Cet. I; Dār Hijrah, 2001. 